\title{
Efeito de mancha de cercospora e produtividade em cultivares de milho no sistema de plantio direto
}

\author{
Manoel Mota Santos ${ }^{1 *}$, João Carlos Cardoso Galvão ${ }^{2}$, Maria Lita Padilha Corrêa ${ }^{2}$, \\ Aurélio Vaz de Melo ${ }^{2}$, Rodrigo Ribeiro Fidelis ${ }^{1}$ e Hélio Bandeira Barros ${ }^{1}$
}

${ }^{I}$ Departamento de Ciências Agrárias e Tecnológicas; Universidade Federal do Tocantins; 77402-970; Gurupi - TO - Brasil. ${ }^{2}$ Departamento de Fitotecnia e Fitosanidade; Universidade Federal de Viçosa; 80035-050; Viçosa - MG - Brasil.

\begin{abstract}
The incidence of attack of the pathogen that transmits gray leaf spot has increased in recent years in the corn producing areas, mainly influenced by successive planting corn after corn, but also by cultivating in late summer, a fact of great importance to promote the increase of the disease. The impact of the disease in the crop is raised to the fact that much of the pathogen colonizes leaf tissue, diminishing the photosynthetic tissue, leading to premature senescence and, consequently, reducing the yield. The research objective this work was to identify the reaction of cultivars to spot the Cercospora and its effect on grain yield of maize. The study was conducted in Coimbra-MG, no-tillage in reduced spacing and population of 83,000 plants ha ${ }^{-1}$. We evaluated the incidence of diseases and grain yield in eight maize cultivars. In the general context, it is concluded that the incidence of cercospora was not influenced by the high plant population and not by the spacing between rows; already obtained more cultivar P 3041 yield.
\end{abstract}

Key words: Zea mays L., nitrogen fertilization, plant diseases

\section{INTRODUÇÃO}

A incidência do ataque do patógeno que transmite a cercosporiose (Cercospora zeae-maydis) tem aumentado nos últimos anos nas áreas produtoras de milho, influenciadas principalmente pelos plantios sucessivos de milho após milho, como também pelo cultivo de safrinha, fato de grande importância para favorecer $o$ aumento da doença. Essa doença tem sido também uma das mais importantes na cultura do milho nos Estados Unidos e em vários países da África. Esse fato está associado à monocultura e à expansão da área cultivada em sistema de plantio direto, que contribuiu para aumentar o potencial de inóculo, através da preservação do patógeno em restos culturais infectados (Casela et al., 2003).

Os sintomas caracterizam-se por manchas de coloração cinza, retangulares a irregulares, com as lesões desenvolvendo-se paralelas às nervuras. Pode ocorrer acamamento em ataques mais severos da doenca. E sua disseminacão ocorre através

*Author for correspondence: santosmm@uft.edu.br de esporos e restos de cultura levados pelo vento e por respingos de chuva. Os restos de cultura são, portanto, fonte local e fonte para outras áreas (Casela et al., 2006).

O impacto da doença na cultura se deve ao fato do patógeno colonizar grande parte do tecido foliar, diminuindo a área fotossintetizante, levando à senescência precoce e, conseqüentemente, à redução da produtividade de grãos (Brito et al., 2007). A cercosporiose do milho é capaz de reduzir de 20 a $60 \%$ a produção de grãos, dependendo da suscetibilidade do híbrido Pinto et al. (2004). Quando a doença ocorre com alta severidade em cultivares suscetíveis, com as perdas podendo ser superiores a $80 \%$ (Casela et al., 2006).

A severidade da doença aumenta em condições de alta umidade relativa e temperatura diurna variando de moderada a alta, bem como em noites frias, com formação de orvalho e, principalmente, quando a temperatura se eleva logo após dias nublados ou chuvosos. Essas condições predominam nas regiões com altitudes superiores a $600 \mathrm{~m}$. Em algumas regiões

J. Biotec. Biodivers. v. 2, N.3: pp. 67-71, Aug. 2011 
tem sido observado ser mais severa nos plantios de novembro (Pinto et al., 2004).

De acordo com Carson et al. (2002), a relação patógeno hospedeiro é distinta entre locais, sendo que, em regiões de produção, frequientemente observa-se significativa interação entre genótipo e ambiente, podendo haver variação na severidade da doença devido à instabilidade dos locos de resistência na interação com o ambiente e/ou diferenças na população do patógeno entre os ambientes.

Além dos fatores mencionados anteriormente, acreditas-se que o aumento da população de plantas associado a redução do espaçamento e adubação nitrogenada de cobertura podem ser um conjunto de fatores que favorece a incidência do patógeno pela formação do micro clima.

Considerando a importância da cercospora, o atraso do plantio e a falta de informações sobre a resistência de cultivares objetivouse com este trabalho identificar a reação de cultivares à mancha de cercospora e seu efeito sobre a produtividade de grãos de milho.

\section{MATERIAL E MÉTODOS}

O experimento foi conduzido de dezembro $(22 / 12)$ de 2006 a junho de 2007, na Estação Experimental de Coimbra, pertencente à Universidade Federal de Viçosa, situada no município de Coimbra, na Zona da Mata de Minas Gerais, caracterizada pelas coordenadas geográficas $20^{\circ} 50^{\prime} 30^{\prime \prime}$ de latitude Sul e $42^{\circ} 48^{\prime} 30^{\prime}$ ' de longitude Oeste, altitude de $715 \mathrm{~m}$, em solo classificado como Argissolo Vermelho-Amarelo distrófico, fase terraço (Embrapa, 2006).

$\mathrm{O}$ delineamento experimental utilizado foi o de blocos casualizados com 4 repetições. Utilizaram-se oitos cultivares de milho comercial da região (1- P 3041, 2- AG 9010, 3- BR 201, 4-UFVM 100, 5- BR 106, 6- DKB 333 B, 7- AG 2060 e 8- DKB 747). Cada parcela experimental foi composta por 5 linhas de $5 \mathrm{~m}$ de comprimento com espaçamento de $0,60 \mathrm{~m}$ entre fileiras e de $0,20 \mathrm{~cm}$ entre plantas. A área útil nos dois espaçamentos foi de $9 \mathrm{~m}^{2}$.

$\mathrm{O}$ experimento foi instalado em sistema de plantio direto na palha em sucessão à aveia preta. Essa espécie de inverno foi semeada na segunda semana do mês de julho e não recebeu adubação de plantio nem de cobertura, apenas irrigação suplementar. No final de outubro, quando as plantas de aveia apresentavam $50 \%$ de florescimento, utilizou-se o herbicida glyfosate $\left(5 \mathrm{~L} \mathrm{ha}^{-1}\right.$ ou $1,8 \mathrm{~L} \mathrm{de} \mathrm{i.a.} \mathrm{ha}{ }^{-1}$ ) para a sua dessecação. A adubação de plantio foi realizada com $480 \mathrm{~kg} \mathrm{ha}^{-1}$ da formulação $8-28-16$ (N P $\mathrm{K}$ ), As adubações de cobertura foram realizadas com uréia, aplicadas em duas épocas (4 ${ }^{\mathrm{a}}$ folha $-105 \mathrm{~kg} \mathrm{ha}^{-1}$ de $\mathrm{N}$ e $8^{\mathrm{a}}$ folha $45 \mathrm{~kg} \mathrm{ha}^{-1}$ de $\mathrm{N}$ completamente expandida), realizando-se uma irrigação logo após a aplicação. Após o desbaste, manteve-se a população de 83.000 plantas $\mathrm{ha}^{-1}$.

O plantio do milho foi realizado 15 dias após a dessecação da área em sistema de plantio direto, com abertura dos sulcos por uma plantadeira/adubadeira, procedendo-se à adubação de plantio e à semeadura do milho, realizadas manualmente através de matracas.

Para o controle de plantas daninhas, utilizou-se a mistura dos herbicidas atrazine + nicossulfuron $\left(1,5 \mathrm{~kg} \mathrm{ha}^{-1}+12 \mathrm{~g} \mathrm{ha}^{-1} \mathrm{do}\right.$ i.a, respectivamente). Os herbicidas foram aplicados em mistura de tanque, quando as plantas daninhas dicotiledôneas e monocotiledôneas se encontravam com 4 folhas e 3 folíolos, respectivamente.

$\mathrm{O}$ rendimento de grãos foi estimado por meio da extrapolação da produção colhida na área útil das parcelas, sendo as mesmas extrapoladas para um hectare, corrigindo-se a umidade para $13 \%$.

A avaliação da severidade de cercospora foi realizada em dez plantas da área útil escolhidas aleatoriamente por meio de uma escala de notas: $1,2,3,4,5,6,7,8$ e 9 , correspondente a: $0 \%, 1 \%, 10 \%, 20 \%$, $30 \%, 40 \%, 60 \%, 80 \%$ e $>80 \%$ respectivamente; baseada na escala diagramática do Guia Agroceres de Sanidade (Agroceres, 1996). A avaliação foi realizada aos 30 dias após a floração do milho. É importante salientar que a severidade foi medida através da infestação do patógeno no campo.

Os dados obtidos foram submetidos à análise de variância, por meio do sistema operacional SAEG 5.0 (Ribeiro Júnior, 2001), sendo as médias dos tratamentos, 
comparadas pelo teste de Tukey, a 5\% de probabilidade.

\section{RESULTADOS E DISCUSSÃO}

As cultivares diferiram significativamente entre si na severidade de doença ao nível de 5\%. Os cultivares apresentaram uma ótima resistência a incidência de cercospora com média de notas variando de 3,40 a 1,00. Essa maior nota foi obtida para o cultivar P 3041, o qual diferiu estatisticamente apenas dos cultivares UFVM 100, BR 106, DKB 333 B e AG 2060. Entre os cultivares, o que apresentou maior resistência ao ataque do patógeno, foi o DKB 333 B $(1,00)$, Tabela 1.

Apesar de haver diferenças estatisticas entre as médias das notas, esses valores são considerados baixos, tendo todos os cultivares classificados como resitentes a mediamente resistentes, de acordo com Guia Agroceres (1996), para essas condições, pois de acordo com Carson et al. (2002), a relação patógeno hospedeiro é distinta entre locais, podendo haver interação entre genótipo e ambiente, ocasionando variação na severidade da doença devido à instabilidade dos locos de resistência na interação com o ambiente e/ou diferenças na população do patógeno entre os ambientes.

Para as condições experiementais, pode-se dizer que a incidência de cercospora não foi influenciada pela elevada população de plantas (83.000 plantas ha $\left.{ }^{-1}\right)$ e também o espaçamento não interferiu no resultado, fato esse mostrado nos resultados obtidos (Tabela 1).

Tabela 1. Reação de cultivares de milho a cercospora avaliada com base na severidade, em cultivares de milho em Coimbra - MG, na safra agrícola 2006/07

\begin{tabular}{ccc}
\hline Cultivares & Severidade/notas & PG \\
\hline 1- P 3041 & $3,40 \mathrm{a}$ & $8040,73 \mathrm{a}$ \\
2- AG 9010 & $2,89 \mathrm{ab}$ & $6398,16 \mathrm{ab}$ \\
3- BR 201 & $2,75 \mathrm{ab}$ & $6535,91 \mathrm{ab}$ \\
4-UFVM 100 & $2,22 \mathrm{~b}$ & $5740,83 \mathrm{~b}$ \\
5- BR 106 & $2,45 \mathrm{~b}$ & $5873,04 \mathrm{~b}$ \\
6- DKB 333 B & $1,00 \mathrm{c}$ & $7411,41 \mathrm{ab}$ \\
7- AG 2060 & $2,10 \mathrm{~b}$ & $6423,20 \mathrm{ab}$ \\
8- DKB 747 & $2,72 \mathrm{ab}$ & $7283,69 \mathrm{ab}$ \\
\hline CV $(\%)$ & 16,06 & 11,86 \\
\hline
\end{tabular}

Médias seguidas por uma mesma letra na coluna não diferem estatisticamente ao nível de 5\% de probabilidade pelo teste de Tukey.

Outra característica que pode ter influenciado esse resultado foi o equilíbrio da adubação, pois segundo Casela et al. (2006), o desequilíbrio da adubação, principalmente a relação nitrogênio/potássio pode potencializar $\mathrm{o}$ aumento de inóculo da Cercospora zeaemaydis.

Em relação à produtividade o cultivar $\mathrm{P}$ 3041 foi superior aos demais $(8040,73 \mathrm{~kg}$ $\mathrm{ha}^{-1}$ ) diferindo somente dos cultivares UFVM 100 e BR 106 com produtividade de 5740,83 e $5873,04 \mathrm{~kg} \mathrm{ha}^{-1}$ respectivamente. Um fato que pode ter contribuído para esse resultado foi à população de plantas associado ao espaçamento reduzido, bem com, ao plantio tardio. Esses resultados concordam com a afirmação de Brito et al. (2007), de que atrasos na época de semeadura, para a região, a partir de 15 de

novembro, promovem redução na produtividade de grãos. Brito et al. (2008), também relatou redução na produção de grãos, neste caso, entre 16 e $38 \mathrm{~kg} \mathrm{ha}^{-1}$ por dia de atraso na época de semeadura, a partir de meados de novembro.

Prado e Goulart Filho et al. (2000), trabalhando com vários cultivares de milho e solos quartzoso encontrou uma produtividade média do ensaio de $3314 \mathrm{~kg}$ $\mathrm{ha}^{-1}$ sendo baixa, embora maior que a média nacional, associou essa baixa produtividade, talvez por excesso de chuva, que ocorreu da 
primeira à terceira semana após emergência das plantas,propiciando maior lixiviação de nitrogênio e potássio, pois se tratava de solo arenoso (140 $\mathrm{g} \mathrm{kg}^{-1}$ de argila). Isto reduziu a disponibilidade nas fases de maior demanda da planta por tais nutrientes. Outro fator, que era esperado foi a própria semeadora tardia, pois Forsthofer et al. (2006) observaram que semeadura tardia em dezembro causou redução na produtividade de três híbridos de milho, comparada à semeadura em agosto. A redução da produção do milho pela semeadura tardia é explicada pelas alterações no ciclo da planta em função basicamente da teniperal uni e da luminosidade (Forsthofer et al.,2006). Sabe-se que cultivares de polinização aberta tem potencial de produção inferior aos híbridos quando plantado em elevada população; e no experimento foi de 83.000 plantas ha $^{-1}$, corroborando com esses resultados.

\section{CONCLUSÃO}

No contexto geral, conclui-se que a incidência cercospora não foi influenciada pela elevada população de plantas e nem pelo espaçamento entre linhas de plantio; já o cultivar P 3041 obteve maior produtividade de grãos.

\section{RESUMO}

A incidência do ataque do patógeno que transmite a cercosporiose tem aumentado nos últimos anos nas áreas produtoras de milho, influenciadas principalmente pelo plantio sucessivos de milho após milho, como também pelo cultivo de safrinha, fato de grande importância para favorecer o aumento da doença. O impacto da doença na cultura é ocasionado ao fato do patógeno colonizar grande parte do tecido foliar, diminuindo a área fotossintetizante, levando à senescência precoce e, conseqüentemente, à redução da produtividade de grãos. Diante disso, objetivou se com esse trabalho identificar a reação de cultivares à mancha de Cercospora e seu efeito sobre a produtividade de grãos de milho. O trabalho foi desenvolvido em Coimbra - MG, em sistema de plantio direto, em espaçamento reduzido e população de 83.000 plantas ha $^{-1}$. Avaliou-se a incidência de doenças e a produtividade de grãos em oito cultivares de milho. No contexto geral, conclui-se que a incidência de cercospora não foi influenciada pela elevada população de plantas e nem pelo espaçamento entre linhas de plantio; já o cultivar P 3041 obteve maior produtividade de grãos.

Palavras-chave: Zea mays L., adubação nitrogenada, doenças nas plantas

\section{REFERÊNCIAS}

Agroceres. (1996), Guia Agroceres de sanidade. São Paulo: Sementes Agroceres, 72p.

Brito, A. H. de.; Von Pinho, R. G.; Pozza, E. A.; Pereira, J. L. A. R.; Faria Filho, E. M. (2007), Efeito da cercosporiose no rendimento de híbridos comerciais de milho. Fitopatologia Brasileira, 32, 18-25. Brito, A. H. de.; Von Pinho, R. G.; Souza Filho, A. X.; Altoé, T. F. (2008)

Avaliação da severidade da cercosporiose erendimento de grãos em híbridos comerciais de milho. Revista Brasileira de Milho e Sorgo, 7, 19-31.

Carson, M. L.; Goodman, M. M.; Williamson, S. M. (2002), Variation in aggressiveness among isolates of Cercospora from maize as a potential cause of genotype-environment interaction in gray leaf spot trials. Plant Disease, 86, 10891093.

Casela, C. R. e Ferreira, A. S. (2003), A cercosporiose na cultura do milho - Circular Técnica 24, Sete Lagoas, MG.

Casela, C. R.; Ferreira, A. S.; Pinto, N. F. J. A. (2006), Doenças na cultura do milho Circular Técnica 83, Sete Lagoas, MG.

Pinto, N. F. J. A.; Angelis, B.; Habe, M. H. (2004), Avaliação da eficiência de fungicidas no controle da cercosporiose (Cercospora zeae-maydis) na cultura do milho. Revista Brasileira de Milho e Sorgo, 3, 139-145.

EMPRESA BRASILEIRA DE PESQUISA AGROPECUÁRIA - EMBRAPA. (2006), Centro Nacional de Pesquisa de Solos. Sistema brasileiro de classificação de solos. Rio de Janeiro, 306p.

Ribeiro Júnior, J. I. (2001), Análises estatísticas no SAEG. Ed. Viçosa, UFV, 301p.

Sawazaki, E.; Dudienas, C.; Paterniani, M. E. A. G. Z.; Galvão, J. C. C.; Castro, J. L.; Pereira, J. (1997), Reação de cultivares de 
milho à mancha de Phaeosphaeria no Estado de São Paulo. Pesquisa Agropecuária Brasileira, 32, 585-589.

Forsthofer et al. Desempenho agronômico e econômico do milho em diferentes níveis de manejo e épocas de semeadura. Pesquisa Agropecuária Brasileira, Brasília, v.41, n.3, p.399-407, mar. 2006
Prado, R. M. e Goulart Filho, L. R. Desempenho em semeadura tardia em vinte híbridos de milho em areia quartzosa do cerrado do triângulo mineiro. Revista de Agricultura, 75, Piracicaba, fascículo 1, 2000. 